
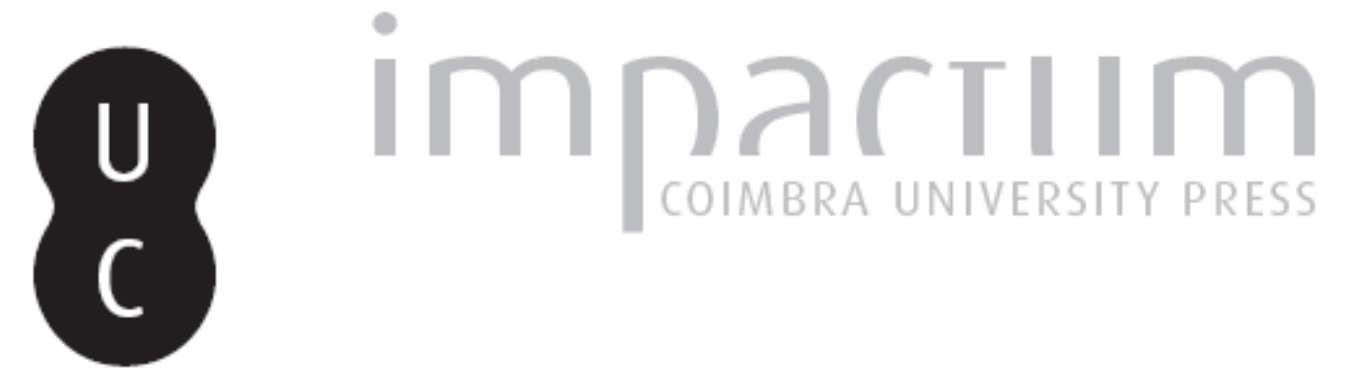

\title{
Reuse of modern schools: public space as a linker
}

Autor(es): $\quad$ Corvo, Atelier do

Publicado por: Editorial do Departamento de Arquitetura

URL persistente:

URI:http://hdl.handle.net/10316.2/45180

DOI:

DOl:https://doi.org/10.14195/1647-8681_9_2

Accessed : $\quad$ 26-Apr-2023 12:40:25

A navegação consulta e descarregamento dos títulos inseridos nas Bibliotecas Digitais UC Digitalis, UC Pombalina e UC Impactum, pressupõem a aceitação plena e sem reservas dos Termos e Condições de Uso destas Bibliotecas Digitais, disponíveis em https://digitalis.uc.pt/pt-pt/termos.

Conforme exposto nos referidos Termos e Condições de Uso, o descarregamento de títulos de acesso restrito requer uma licença válida de autorização devendo o utilizador aceder ao(s) documento(s) a partir de um endereço de IP da instituição detentora da supramencionada licença.

Ao utilizador é apenas permitido o descarregamento para uso pessoal, pelo que o emprego do(s) título(s) descarregado(s) para outro fim, designadamente comercial, carece de autorização do respetivo autor ou editor da obra.

Na medida em que todas as obras da UC Digitalis se encontram protegidas pelo Código do Direito de Autor e Direitos Conexos e demais legislação aplicável, toda a cópia, parcial ou total, deste documento, nos casos em que é legalmente admitida, deverá conter ou fazer-se acompanhar por este aviso.

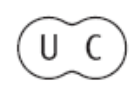



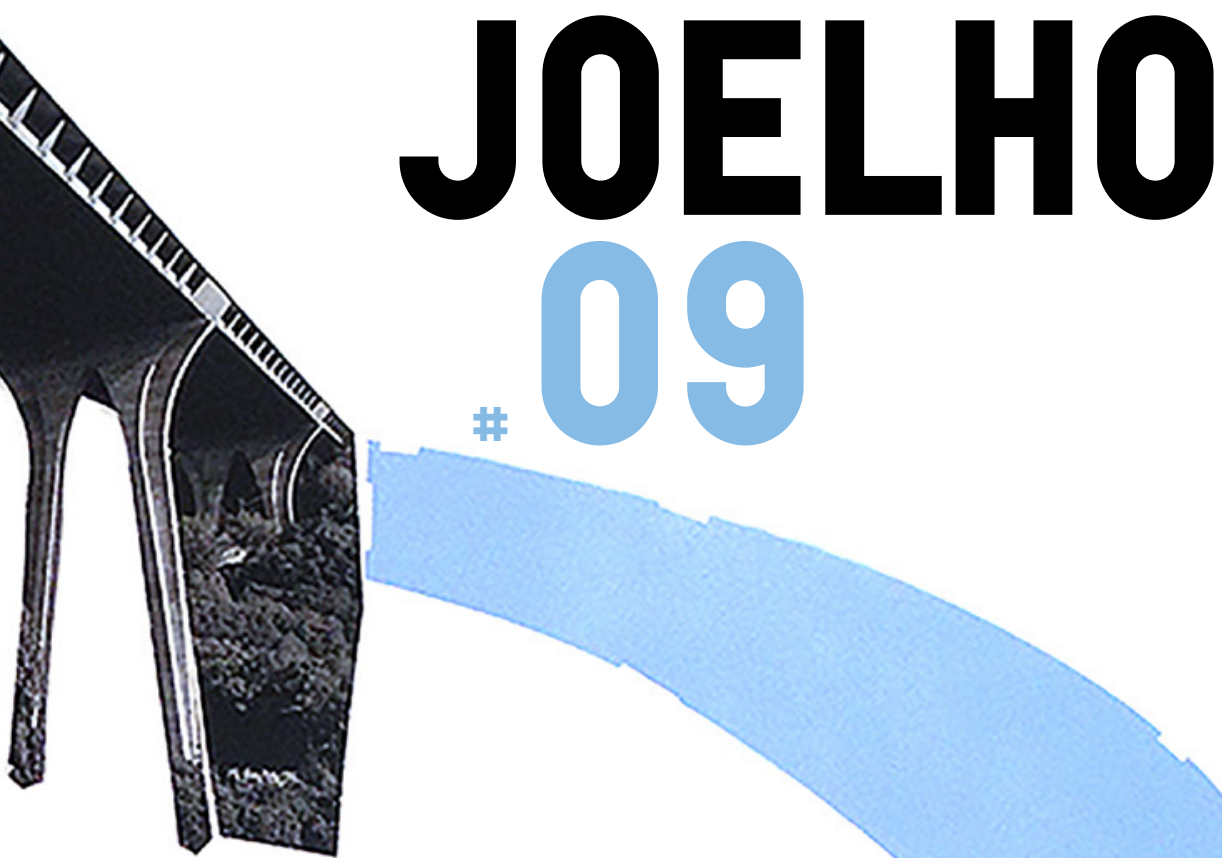

\section{REUSE OF MODERNIST BUILDINGS: PEDAGOGY AND PROFESSION}

Guest Editors:

Michel Melenhorst

Paulo Providência

Gonçalo Canto Moniz

ZUS: Elma van Boxel

and Kristian Koreman

Atelier do Corvo

Tilemachos Andrianopoulos

Albena Yaneva

Carlos Fortuna

Christian Gänshirt

Dieter Leyssen

Carolina Coelho

Anna Giovannelli

António Carvalho

Marta Peixoto

Els De Vos

and Eva Storgaard

Exhibition

$2^{\text {nd }}$ RMB Workshop, Coimbra

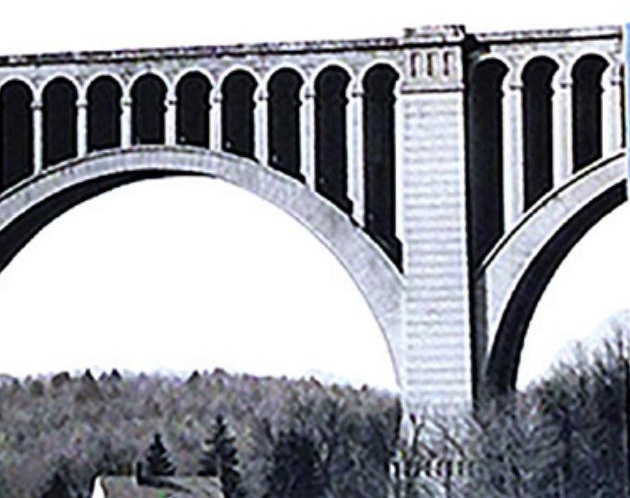




\section{Atelier do Corvo}

\section{Reuse of Modern Schools:}

\section{Public space as a linger}
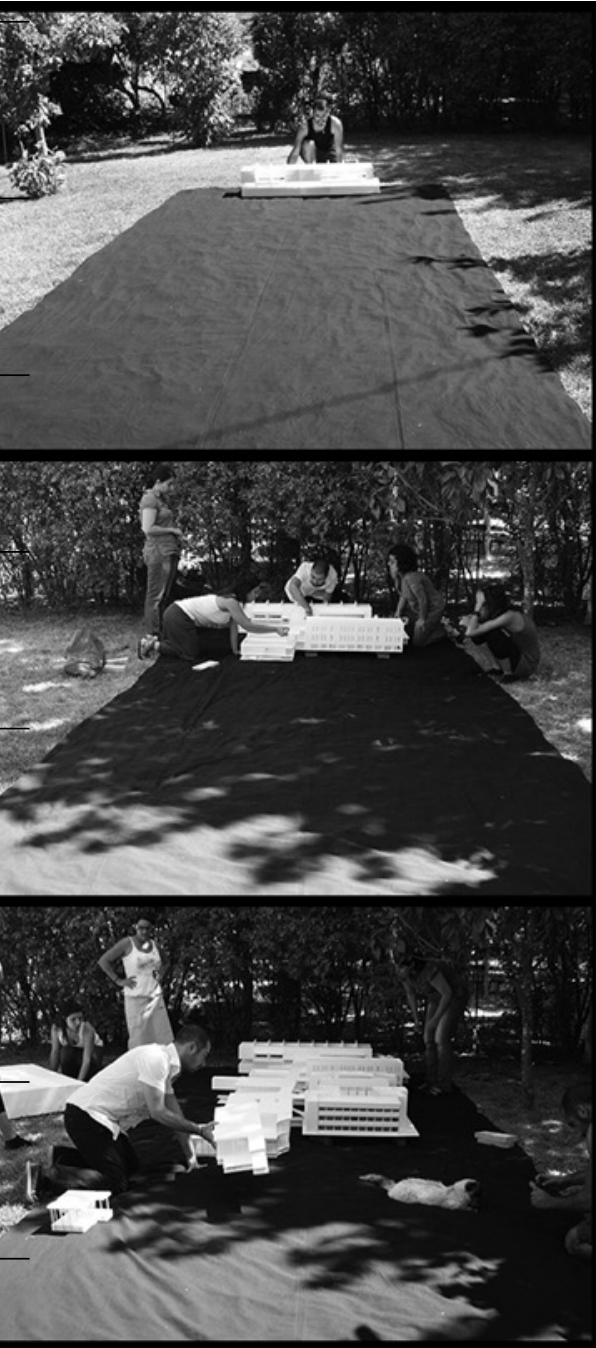
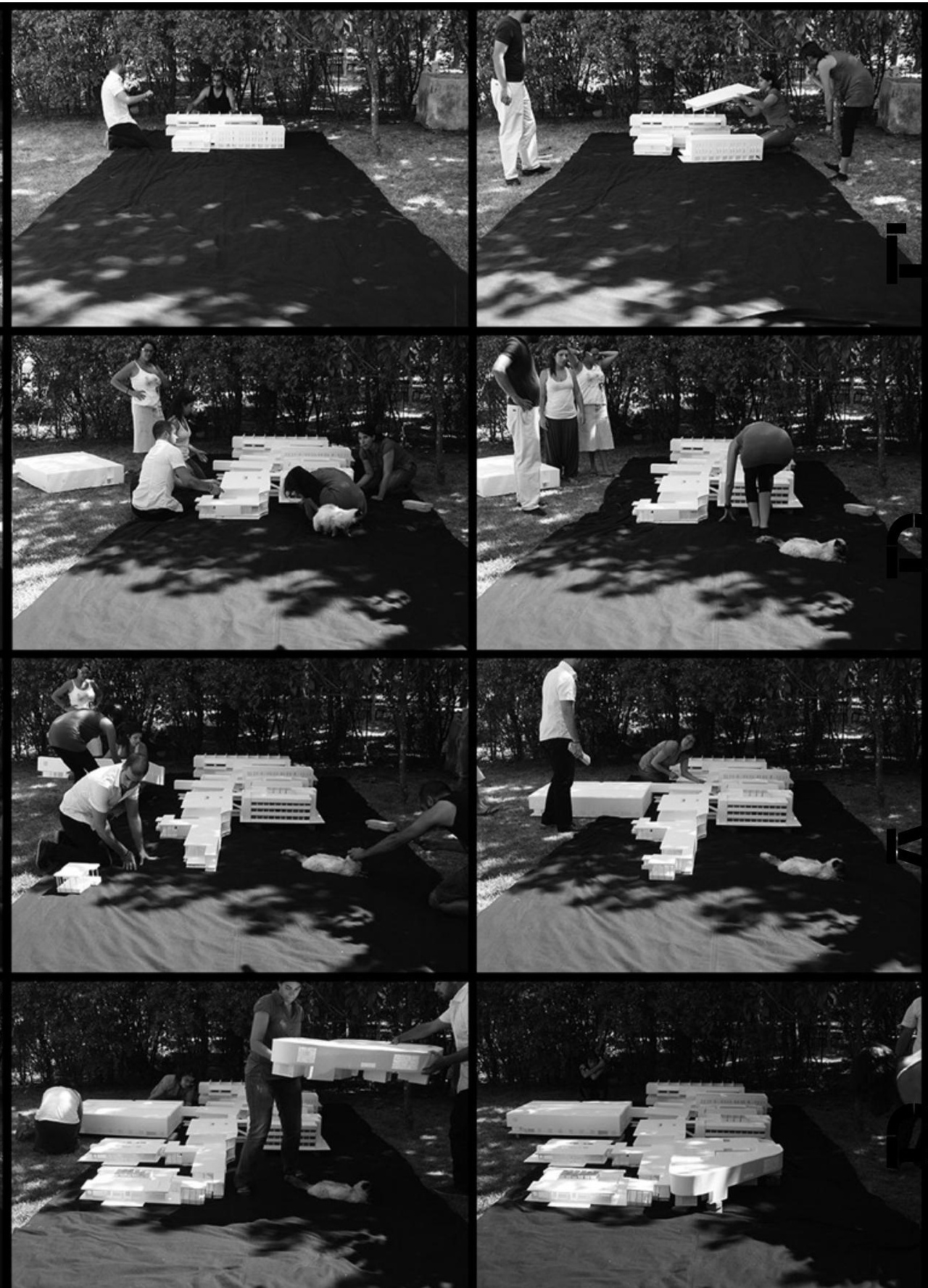


\section{Introduction}

The two projects selected for the Reuse of Modernist Buildings are examples of our way of understanding this subject. These projects are neither typical rehabilitations, nor refurbishment, but an intense exchange between the diverse existing layers and the new ones required.

The aims of these projects focused on giving clarity to the existing facilities and removing the ambiguities which resulted from the successive additions and uses to which the building has been subjected to over time, thus enabling a clear proposal for new buildings. In these projects, the renovation and remodelling of existing structures, as well as the proposal for new constructions, was grounded on the principle of a dialogue between the existing and the new, between the past and the present.

These projects even though having dissimilar context, were able to respond to the new functional programmes without loosing their identity, although they have become more complex and dense. They both have in common the public space as a linker between the internal organization of the several blocks of each school and between each school block and the city. In one school the link is a square, in the other it's a street. These two structural elements are also essential in the internal reorganization of each school, allowing us to understand them as a city were they gave coherence to sum blocks throughout decades. On the border between the exterior and the interior, visual connections were essential to establish and accentuate the continuity of one another.

In both projects the skin is used as a technical, formal and symbolic element. The phenomenological approach of the skin as a surface was not our main goal, but it is not possible to deny the importance of the skin/cloth of Joseph Beuys that protects and heats the sick body. This metaphor was present in the material selected for each school, that allows the buildings to have new infrastructure that is able to increase their response to the energetic efficiency of the entire construction system, without loosing their specific features.

The engagement of the school community in the design process was different in each school. In Pombal the briefing was made by the school board, that had collected all the functional needs before. Each meeting was more to show the work-in-progress than to dialogue about it with the representatives of the school community. In Batalha, the briefing was the result of a proper adjustment of several meetings that were an intense dialogue between architects and the school community.

In both cases, the models had an important role in all the meetings because they triggered more complex responses from both sides.

In our design process, the models at scale, at real scale or without scale, have being central. This specificity expresses itself materialized in the model, that sometimes happens before forms and programmes appears. Sometimes form and function are defined by the first model, because models are not only reproduction or anticipation,
Frontispiece Batalha School, Frames of the model workshop session. 
but already the synthesis of a work, or to say in other words, the real and its representation stand in suspension. The model is not only a representation of something. It is also a statement about the very essence of architecture. Space and form, absence and presence translated to reallity in a more abstract language.

In these projects, once again, the models allowed us to work in the representation of the space to be.

The similarities, previously said, between these two projects can be synthesized as a result of a design process that considers the physical and social context in which these buildings exists.

\section{Modernization of Pombal Secondary School, Former Industrial and Commercial School}

\section{Context and background}

Pombal Secondary School was inaugurated in 1958, a project of the Ministry of Public Works (Board of Constructions for Technical and Secondary Education) which was formalised in June 1950. It was initially designed as an Industrial and Commercial School, and nowadays functions as a Secondary School.

It was part of the general construction of the school estate designated phase 2, implemented between 1936 and 1968. Construction was carried out according to a plan implemented by the Ministry of Public Works through the Board of Constructions for Technical and Secondary Education (JCETS-MOP) which aimed to structure the country with teaching facilities which could meet the younger population's real learning needs.

After a 50-year life cycle with notable quality, the whole facility needed renovation both for conservation purposes and also to enable it to adapt to the needs of the programmes demanded in the new education plans and to the current socio-cultural circumstances.

Fig. 1 Pombal Secondary School photo archive. Date and author unknown.

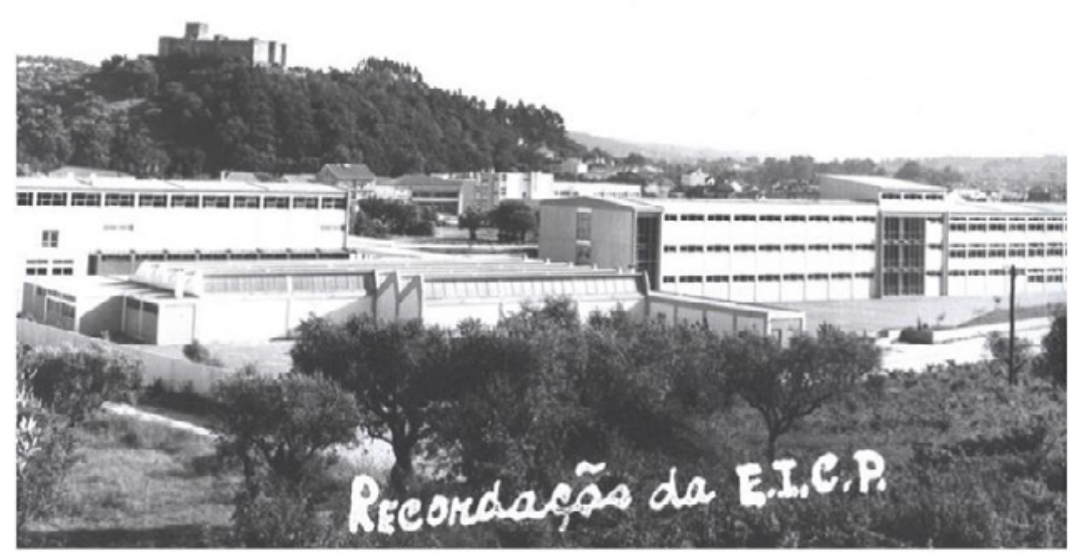


The school is composed of autonomous blocks, which extend longitudinally west to east, with a length of $160 \mathrm{~m}$, from which two wings extend to the south. In the south-east is the cafeteria and gymnasium body, and the workshops body is in the north-east.

In terms of construction, the school is a porticoed structure of reinforced concrete with exterior walls of masonry in $15 \mathrm{~cm}$ hollow brick. The structural portico is clear from the outside.

\section{Proposal}

This is a complex intervention, the essence of which can be summarized as follow:

- Reorganization of the functions of the school

- Demolition of obsolete structures

- Optimizing the use of the existing area and increasing the useable area to allow new programmes to be introduced.

- Increasing the passive and active energy efficiency of the entire construction system.

\section{Reorganization of the functions of the school}

The issues related to the reorganization of the functions of the school are of two different orders. The first has to do with the relationship of the school as institution - its buildings and its programme - with the social and urban fabric in where it is placed. The second is internal in nature and has to do with the proper functioning of the school and the relationship between its organic units.

\section{Connecting the building to the city}

One of the main objectives of the programme defined for the renovation of the School Estate was to reintroduce the social importance of the

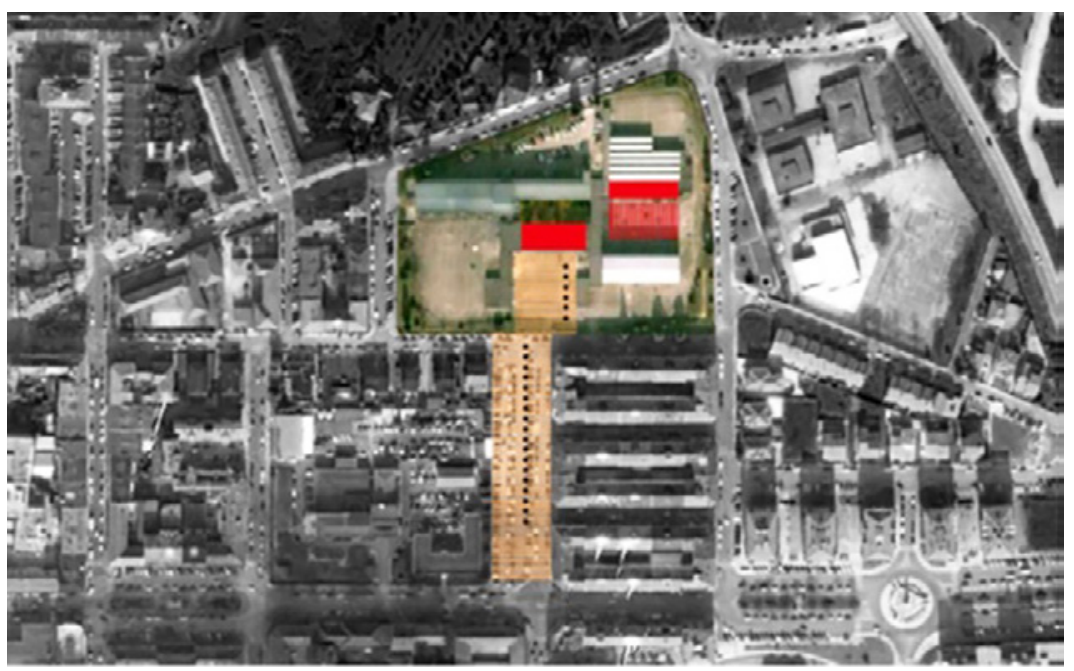

Fig. 2 Photomontage over image taken from Google Earth @ Atelier do Corvo 
school in the functioning of the social fabric where it was placed, and that the school facilities should be used by the general community. We considered this condition to be an essential support for our proposal for a new entrance to the school, with better coordination and a better relation to the surrounding urban fabric. We proposed moving it from the extreme west of the building to a more central position between the two wings which extend south, also considering that this option allows a reduction in internal movement and a more effective spatial relation between the different constituent parts of the curricular programme.

This space is defined by the building which extends longitudinally, the two perpendicular arms and the south side of the building, in continuity with an open large space used as a car park. We felt that it had unique conditions to give greater clarity and urban effectiveness to the relationship between school and city. Thus, we proposed the creation of two directly coordinating squares: one belonging to the city, instead of the current car park which would then be under this new public space, and another inside the school grounds. The flooring plan for these new squares should be the same so that the spaces could be considered continuous. However, the outer square was not approved due to a lack of political resolve on the part of municipal officials.

The new square inside the school precinct created an outdoor atrium for school users. In the visual finishing of this square, we proposed a new building that would extend this function of welcoming and receiving the users inside. We believed it essential to design the atrium in accordance with the institutional aspect that a school with this size and importance to the local social fabric should represent. In addition to this function, the new library, which, according to the prerequisites defined by the School Estate project should be understood as the heart of the school, a place of great centrality and representativeness, is also located here, alongside the mini auditorium. These spaces can also be used by the non-school community which is another reason for placing them here, as it allows them to be used autonomously from the normal functioning of the institution.

\section{Reorganization of the functions and internal organization}

This school was used over a long period of 50 years and was managed by various personalities responding to very different educational programmes. It is for this reason that the solutions for functional problems that had arisen were made on a case-by-case basis, without a vision for the whole school. This use resulted in a dispersal of the school's curricular programmes and functions that we aimed to correct.

The new organization of the building's functions was designed in conjunction with the school's directors and faculty and the student and employee representatives. This organization sought to concentrate curricular programmes into organic and functional units. 


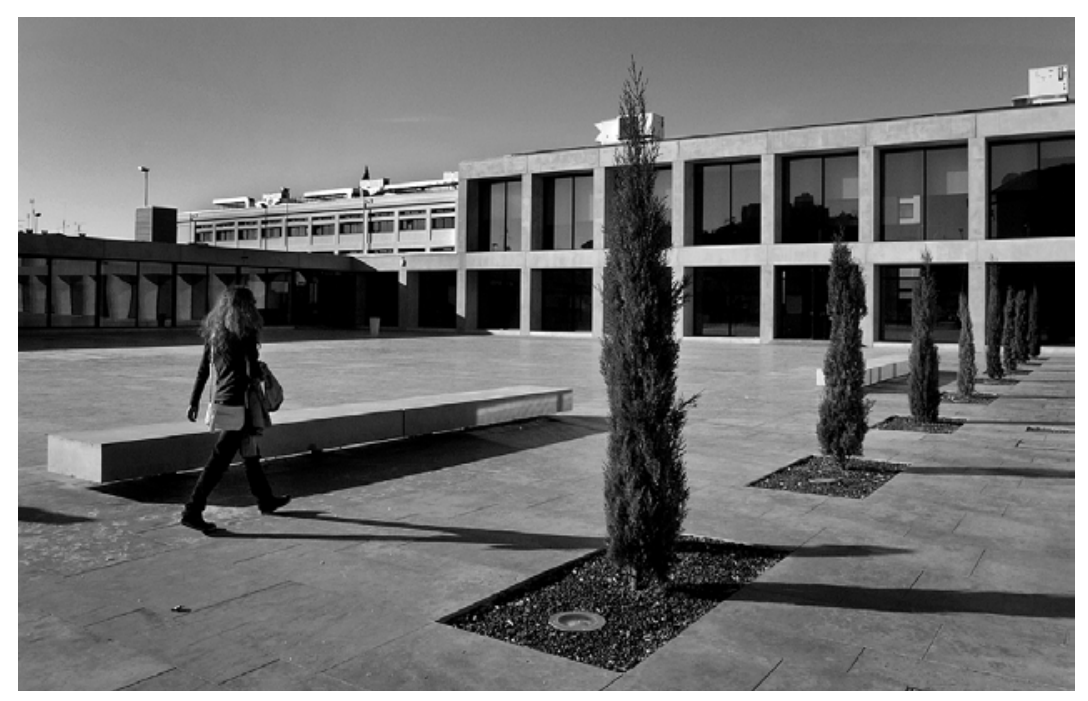

Fig. 3 New entrance @ José Menezes

Fig. 4 School square @ José Menezes

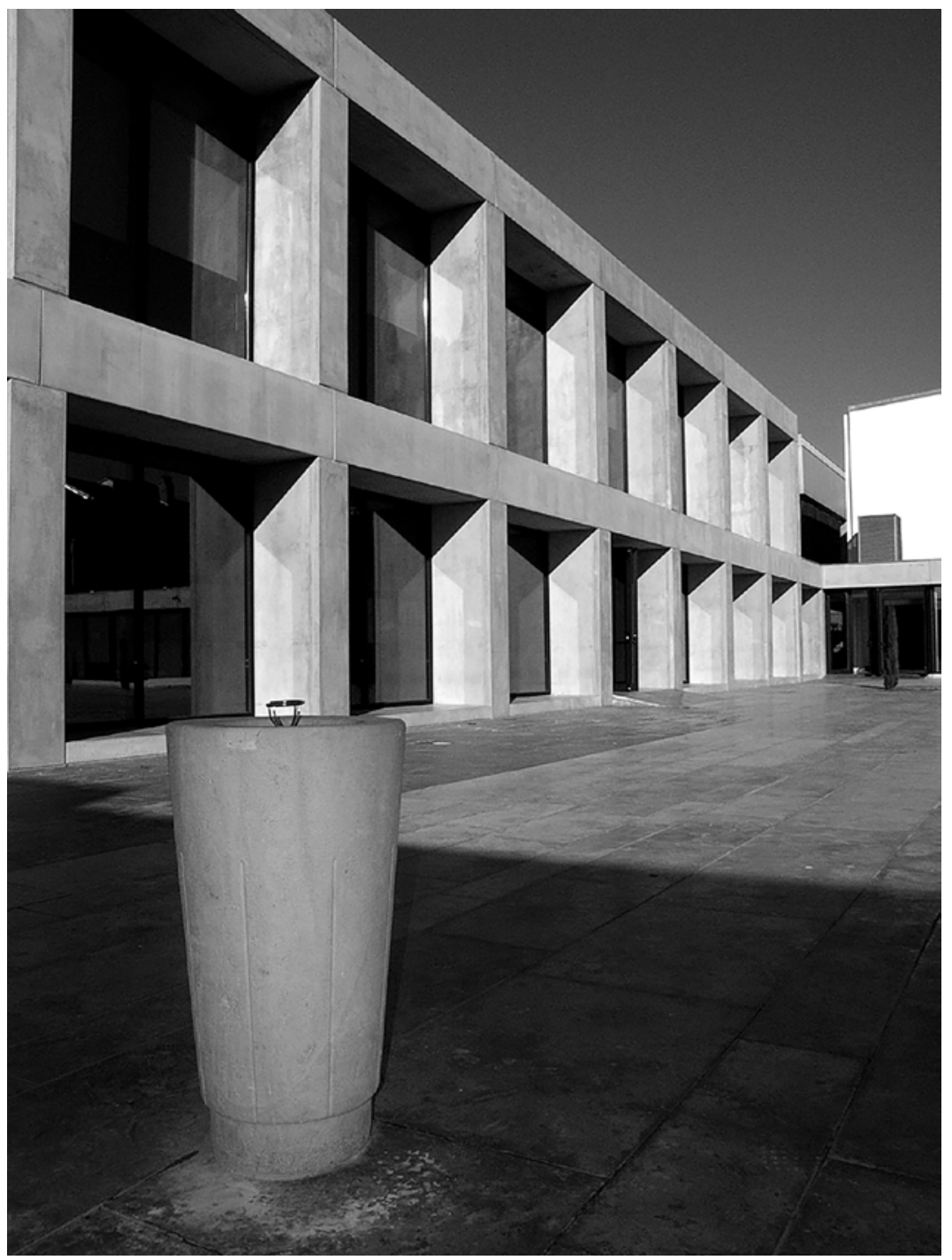


Fig. 5 e 6 Library @ José Menezes

Fig. 7 New proposal for the distribution of functions

@ Atelier do Corvo
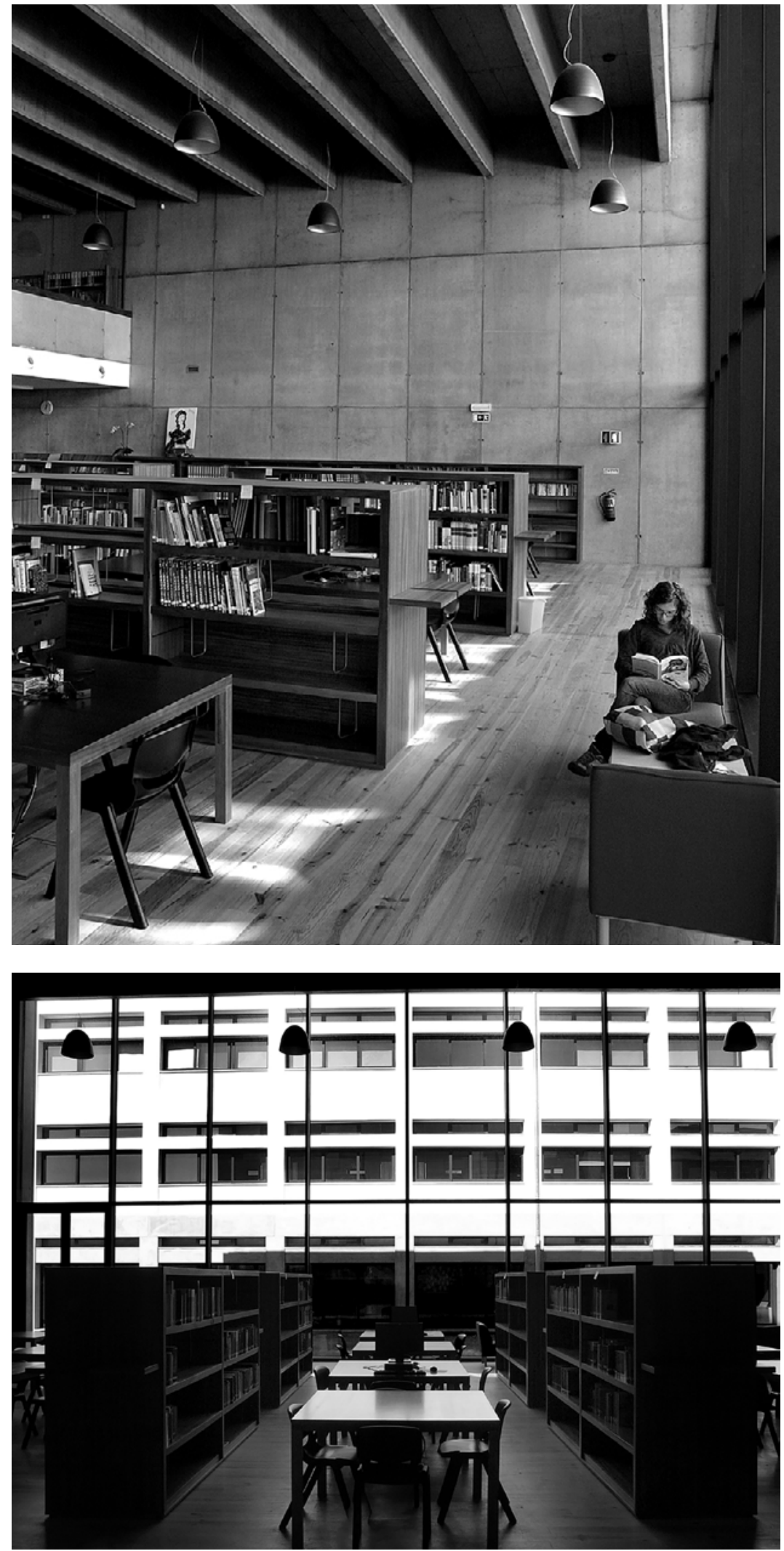


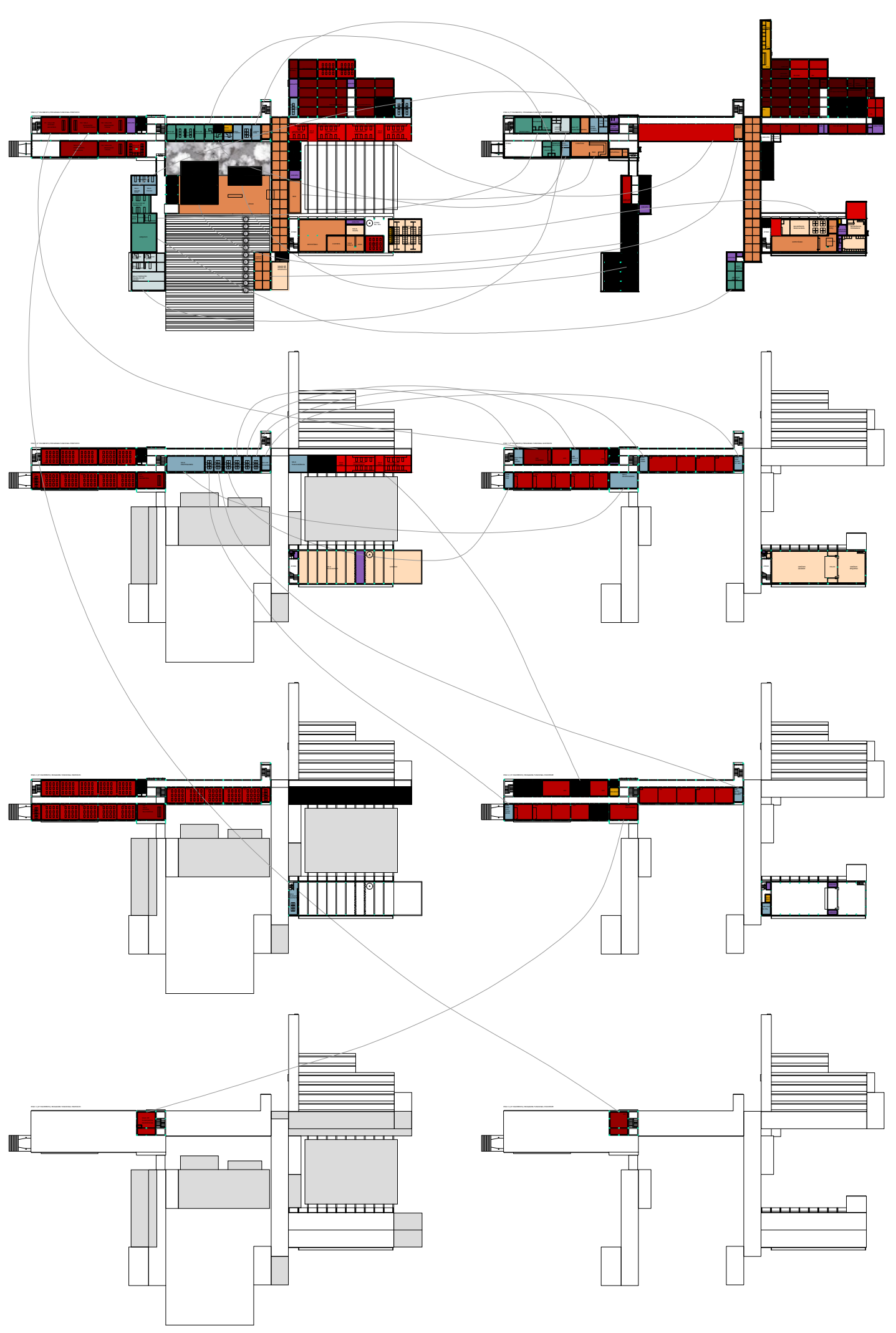


Fig. 8 New entrance, gymnasium area @ Atelier do Corvo
As previously mentioned, the atrium, the library and informal study room and the mini auditorium are located in the new central body. It is this block that allowed the distribution to the diverse functional units to be organized.

Included in more significant interventions, we should also mention the complete reformulation of the workshop block, the creation and installation of infrastructures of the laboratories, the rehabilitation of the gymnasium, along with a total reformulation of the canteen and the enlargement of the small gymnasium area and roofing for the sports fields to the east. The entire two-storey north-east wing, next to the workshops, was replaced by a new building as it lacked sufficient area, making the classrooms small and inadequate.

\section{Demolition of obsolete structures}

It was necessary to carry out a series of demolitions in order to implement the architectural solution. Some of them were made to ensure the energy efficiency of the building, others were the result of

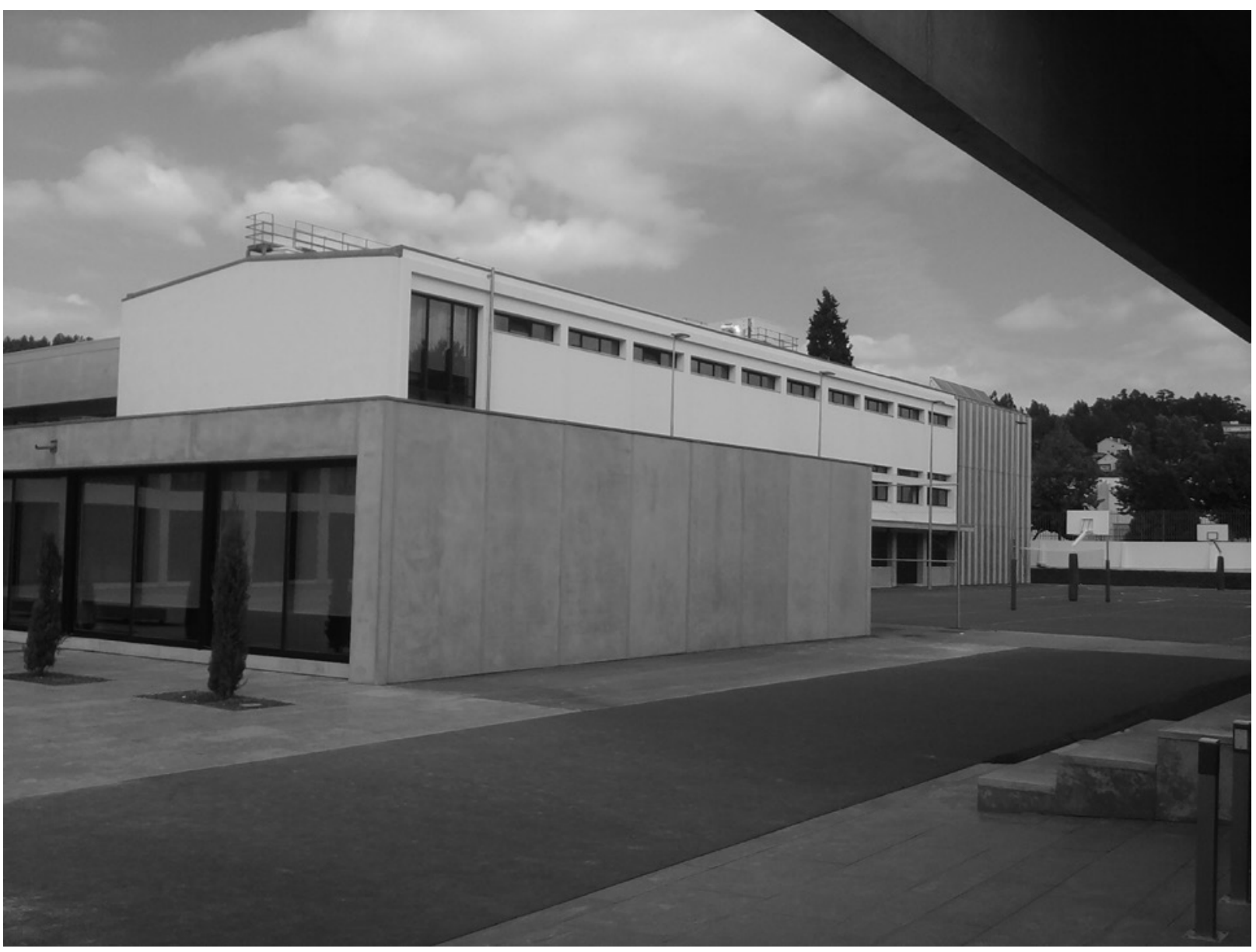


claryfing the new uses of existing blocks, achieve the requirements of regulations and also the need to increase the area of classrooms, gymnasium, cafetaria and refectory.

Altering the main entrance of the school no longer made it necessary to have walls and railings by the entrance, and thus this space can now be part of the interior of the school. This option enables a physical education circuit training route to be created around the whole school.

\section{Optimizing the use of the existing area and increasing the net area to allow the introduction of new programmes}

The Knowledge and Memory Space, a museum area at the end of the distribution corridor, was slated to be in the former atrium. This body brings together all spaces linked to teaching of the arts and other classrooms which need no special logistics or equipment.

The tympana that close the east portico was demolished, thus making a direct relationship with the new square, separated only by a glass panel with aluminium frame.

The administration department, attendance for parents/guardians and training courses for the non-school community are located in this building. Despite its unusual location, it is central to the school's functions, a "learning street", due to the curricular programmes it houses.

A new block was added to increase the gymnasium area, restructure the changing rooms and give the kitchen and dining room the technical areas which they needed to function properly.

The exisiting workshops block was completely reworked, with no significant changes in volume being made.

Basically, the aim was to clarify the space of the building by concentrating the workshop rooms into nuclei, separating them from the classrooms or design rooms.

The aim was to establish a visual relationship between the workshops body and the rest of the school buildings, replacing the existing wall with glass panes in a steel frame.

New reception atrium with distributes to the various working areas of the school to create a cadenced sequence between the outside and the inside, between the ground level and the upper gallery. This was done through different ceiling heights and measurements of structure and fenestration. The use of the concrete inside, along with iroko wood, gives it the institutional aspect that a place of this nature merits.

The covered sports fields, with a structure of prefabricated concrete beams supported on four pillars in the same material, executed in situ, and a canopy of polycarbonate honeycomb panels, fulfilled the purpose making their use possible regardless of the weather conditions.

A new gatehouse next to the main south entrance to the school does the transition between the two squares, the city and the school ones.

The outside areas were physically enclosed by railings that delimited the plot and by the existing buildings. 
Fig. 10 Library, mini auditorium and informal study room atrium @ Atelier do Corvo

Fig. 11 New gatehouse @ José Menezes
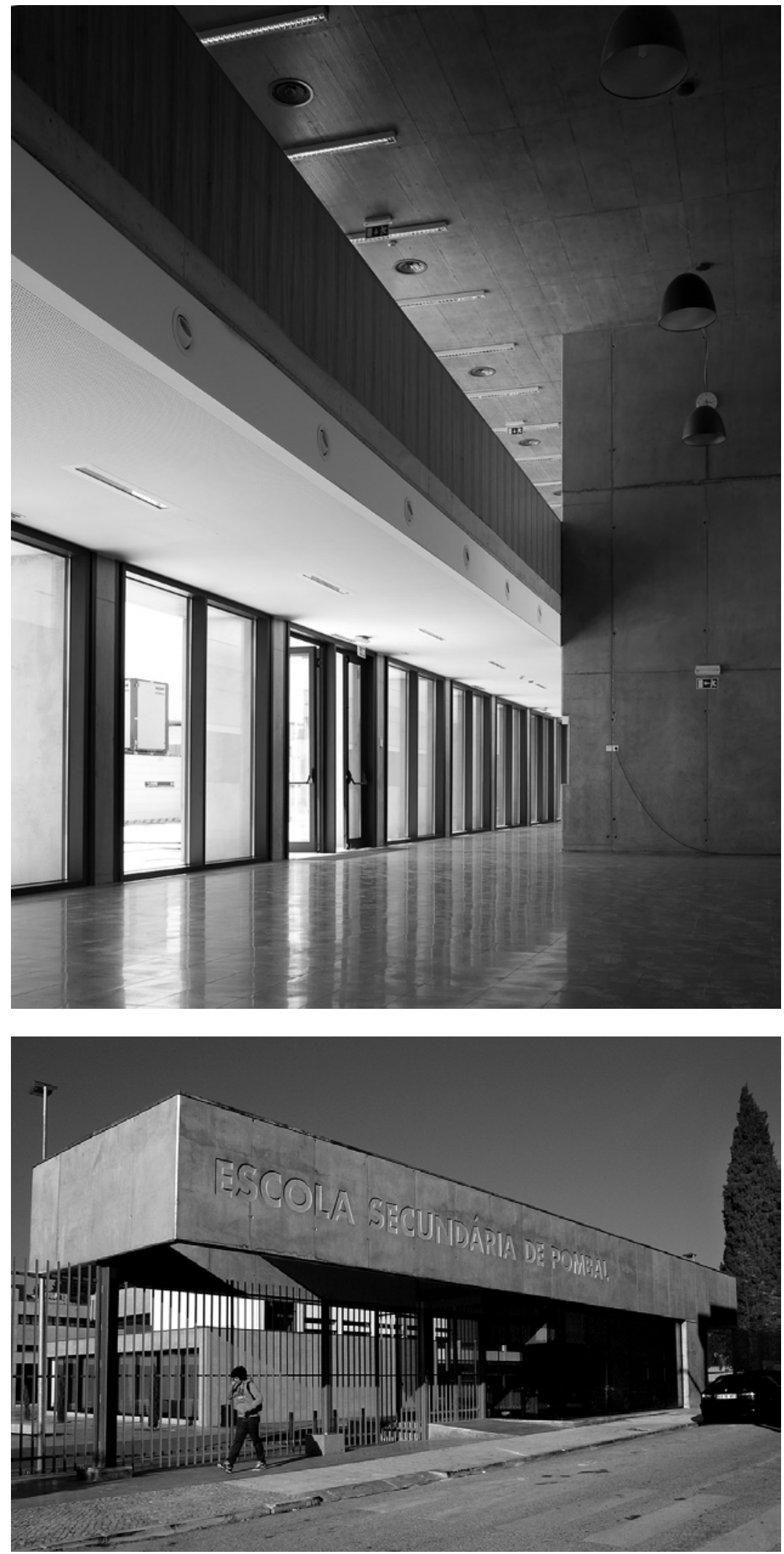
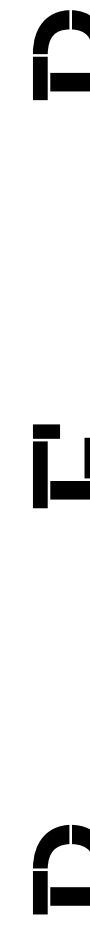
The interior garden was designed in conjunction with the school community, to be enjoyed for both leisure and education. It was planted with garden species and small vegetable plots for research. However, this project is not complete, and has not been implemented yet.

\section{Improved passive and active energy efficiency of the whole construction system and renovation of all infrastructures}

The building had deficiencies in its structural behaviour, particularly serious regarding its energy efficiency.

In this new intervention, the building was equipped with all the technical infrastructures necessary for excellent energy efficiency and compliance with current standards of comfort.

The proposal catered for two generic solutions for facades:

For the facades of pre-existing buildings, the option was to clad the walls with the ETICS system on the higher floors and with GFRC on the ground floor. The application of the two coating systems proposed ensured a level surface.

The use of GFRC on the ground floor of pre-existing buildings, but also in the full cladding of the new constructions around the square, creating a regular cadence for the system of construction and infrastructure, provided a strong and striking image, simultaneously representative and austere, in an attempt to reinterpret the formal message that this school originally transmitted.

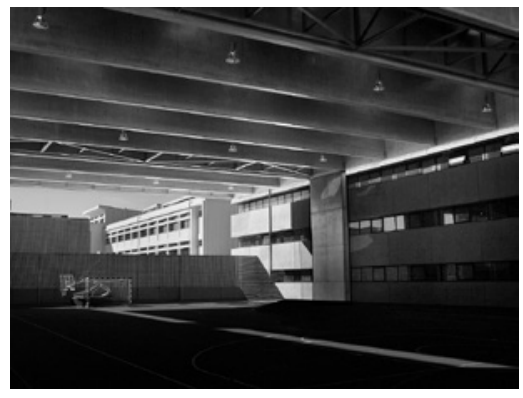

Fig. 12 Covered sports fields @ José Menezes

Fig. 13 Study for library, mini auditorium and informal study room atrium @ Atelier do Corvo

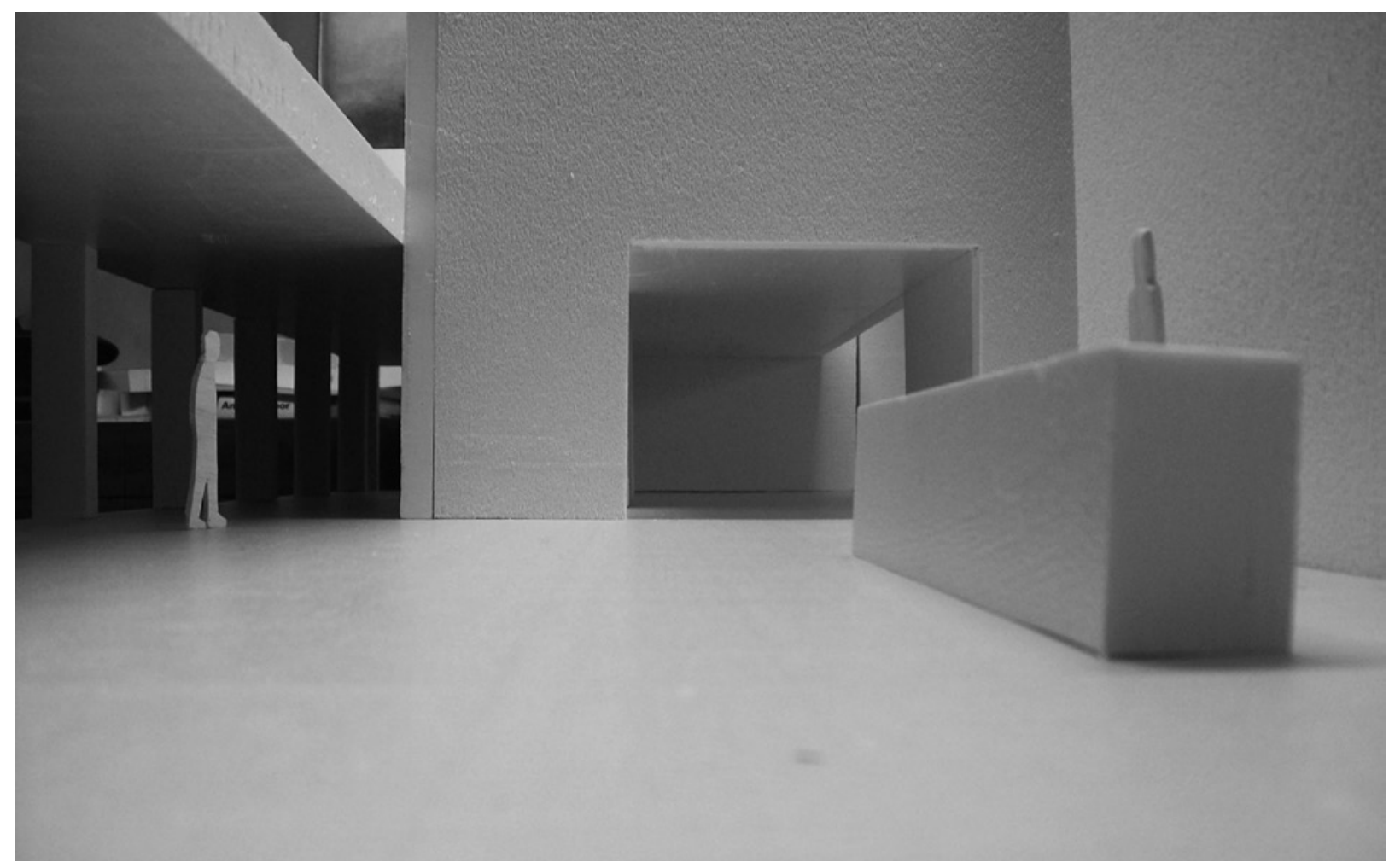


Fig. 14 1:500 model general view (a) Atelier do Corvo

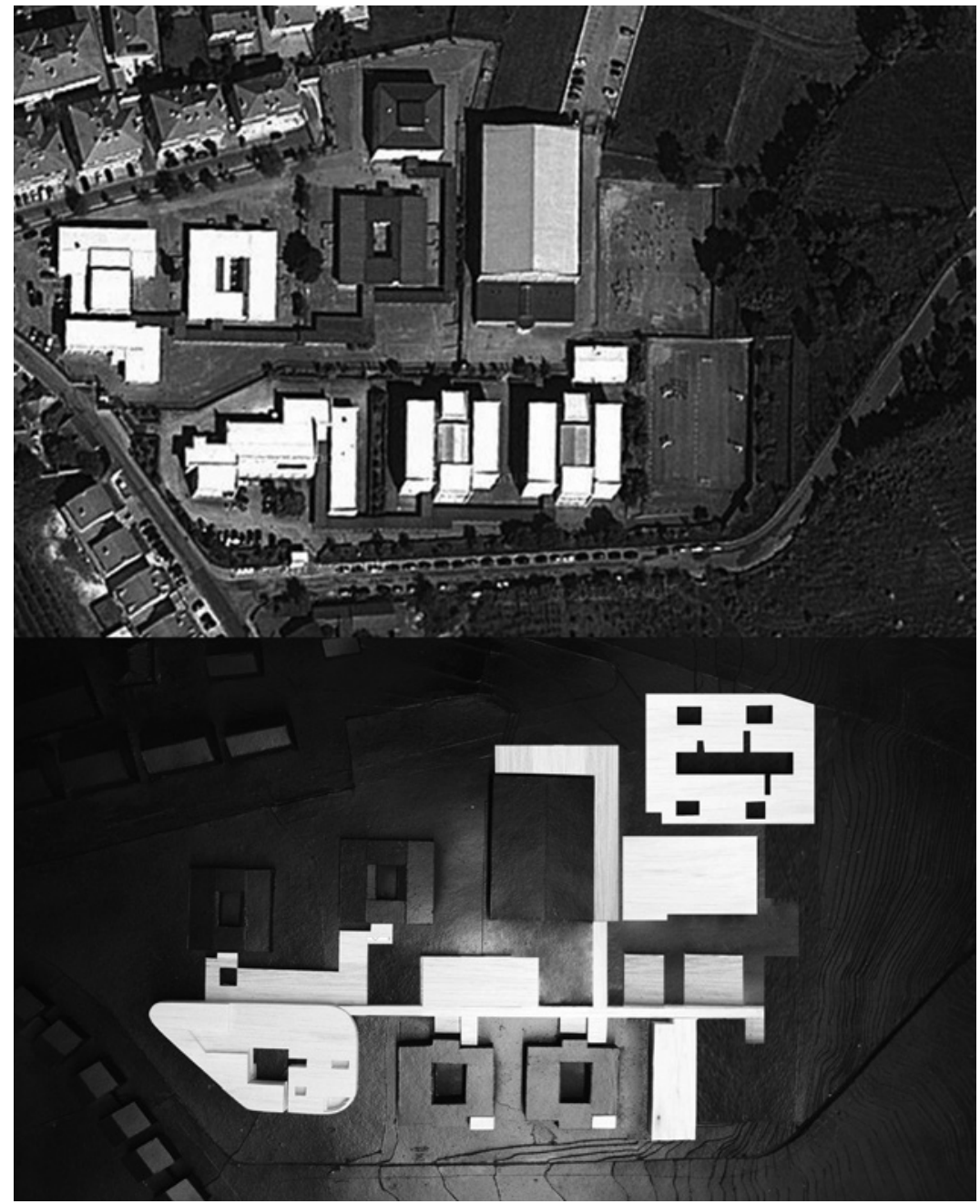

\section{Modernization of the Batalha Basic and Secondary School and the Professional School of Arts and Crafts}

\section{Typological profile}

Batalha's Secondary and "Preparatory" schools, 1st and 2nd cycles, consist of a set of autonomous blocks connected by covered exterior walkways. They have buildings from the 70s, 80 s and 90s, which are based on the "type project" models.

At the end of the 1960s, a limited set of "type projects" was developed for high schools, technical schools and preparatory schools. The projects were highly pragmatic in order to ensure speed and economy of execution and were designated Standard Type Projects. The construction strategies dictated an image for the buildings devoid of all ornamentation.

These type projects were constructed from a set of autonomous blocks, allowing the building to be adapted to plots of land with very 
diverse characteristics of geomorphology, exposure and access which were unknown a priori. The different blocks were connected by covered exterior walkways, the layout of which depended on the morphology of the land. This flexibility in adapting to the terrain allowed work to be done on the inner space of the blocks, by means of the unevenness of the various areas that constitute them, leading to a more complete adaptation to the local characteristics.

The Standardized Study of the preparatory school consisted of a block with one and a half storeys where the administration, reception, cafeteria, library and multipurpose hall were located. There were also blocks of classrooms with a single quadrangular floor and an open central quadrangle. Internal movement took place via the teaching spaces.

These solutions were reproduced in various parts of the country, specifically adapted to the size of the school and the plot where it was placed.

In the 80s, a new type project was developed that maintained the structure of pavilions with outside connections via walkways. This project, called " $3 \times 3$ ", consisted of two types of blocks:

1) a two-storey square block with a staircase located in the centre and natural light from skylights, intended for educational and administrative activities;

2) a single-storey rectangular block for the cafeteria, kitchen and student room.

In terms of construction, they are modular buildings with a porticoed structure of reinforced concrete and slabs of the same material, with the walls built in brick masonry, plastered and painted with some apparent concrete features. The roofing is flat and not intended for access or sloped with skylights and lined with fibre cement boards. The windows have wooden or aluminium frames and have a single-glazing pane with aluminium.

\section{Project proposal}

The main prerequisites of the proposal were:

- Defining the plot of land for intervention by opening up the street north of Rua do Freire and connecting it with the street parallel to Estrada do Casal Novo. This will make space for a road with clear distribution. To this end, the current 1st cycle block will be demolished.

- Creating a square parallel to Rua do Freire, giving visual continuity with the outside space of the school. This act will allow the street to be balanced by the creation of an outside reception atrium for school users. 
Fig. 15 Render west view @ Atelier do Corvo

Fig. 16 Render east view @ Atelier do Corvo
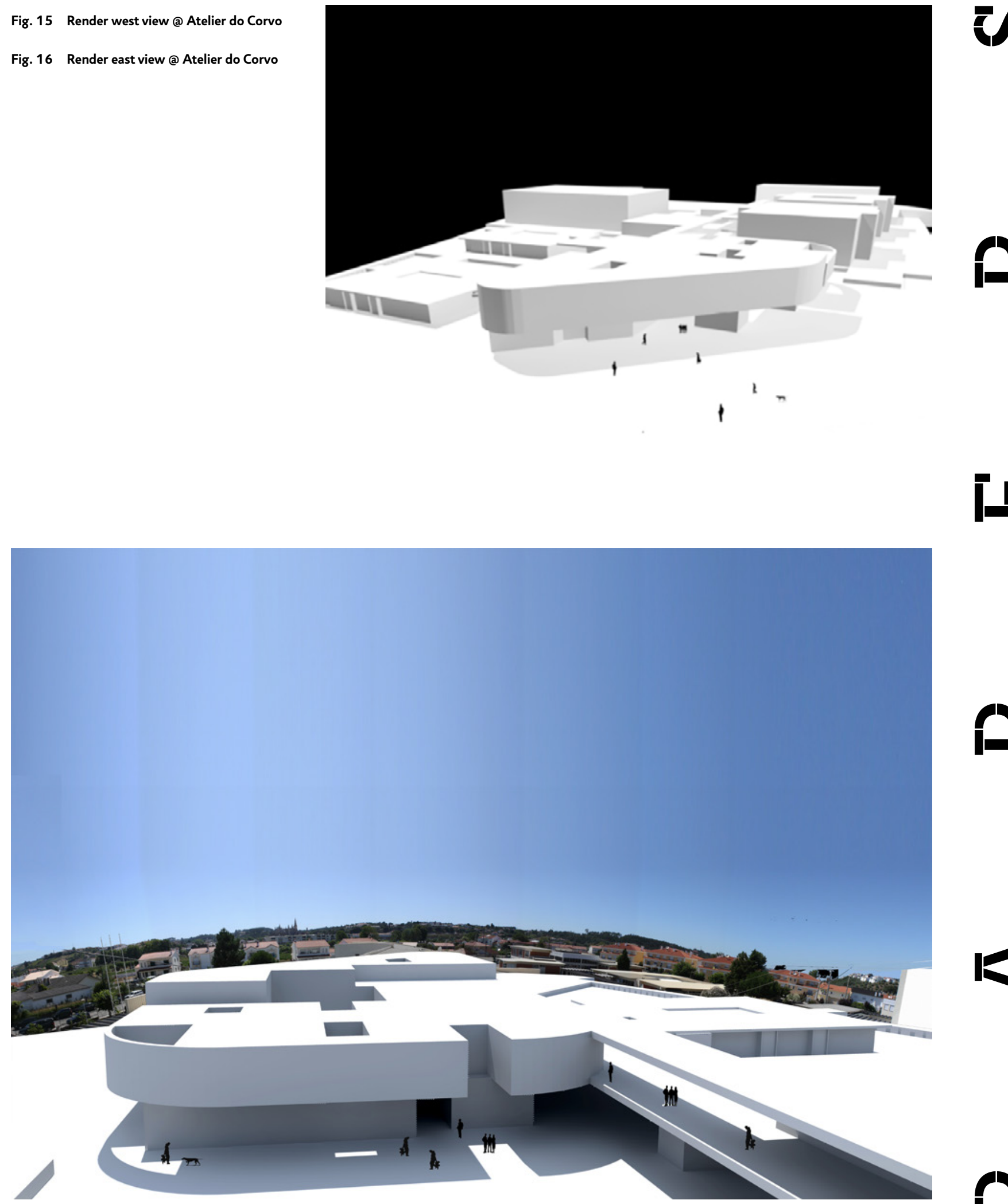
- A central body in the square, unusual in its location with the remaining buildings but, when formalized, will be a representative feature, where the gatehouse and other parts of the programme for common use will be located.

- Another body coordinated with the previous one, a learning street, which will allow a connection between the other spaces of the school. Next to this, several organic and functional units are distributed, which constitute formal units.

- A new block where specific curricular rooms and design rooms and laboratories will be located, adjacent to a quadrangle facing the east slope.

- A covered multipurpose pavilion installed halfway between the current gymnasium and the workshops.

- A 1st cycle school with autonomous access, strategically located in relation to the new proposed road distribution network. It will have designated play areas which integrate with and become part of the building itself.

- Outside spaces associated with themes, which will be related to their target age groups.

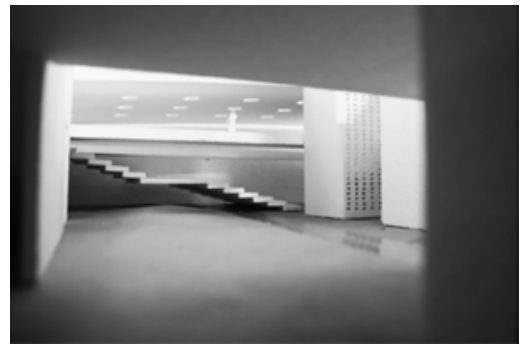

Fig. 17 Informal auditorium @ Atelier do Corvo

Fig. $18 \quad$ 1:100 model of the $2^{\text {nd }}$ learning cycle module @ Atelier do Corvo

Fig. 19 1:100 model of the $2^{\text {nd }}$ learning cycle module, interior view @ Atelier do Corvo
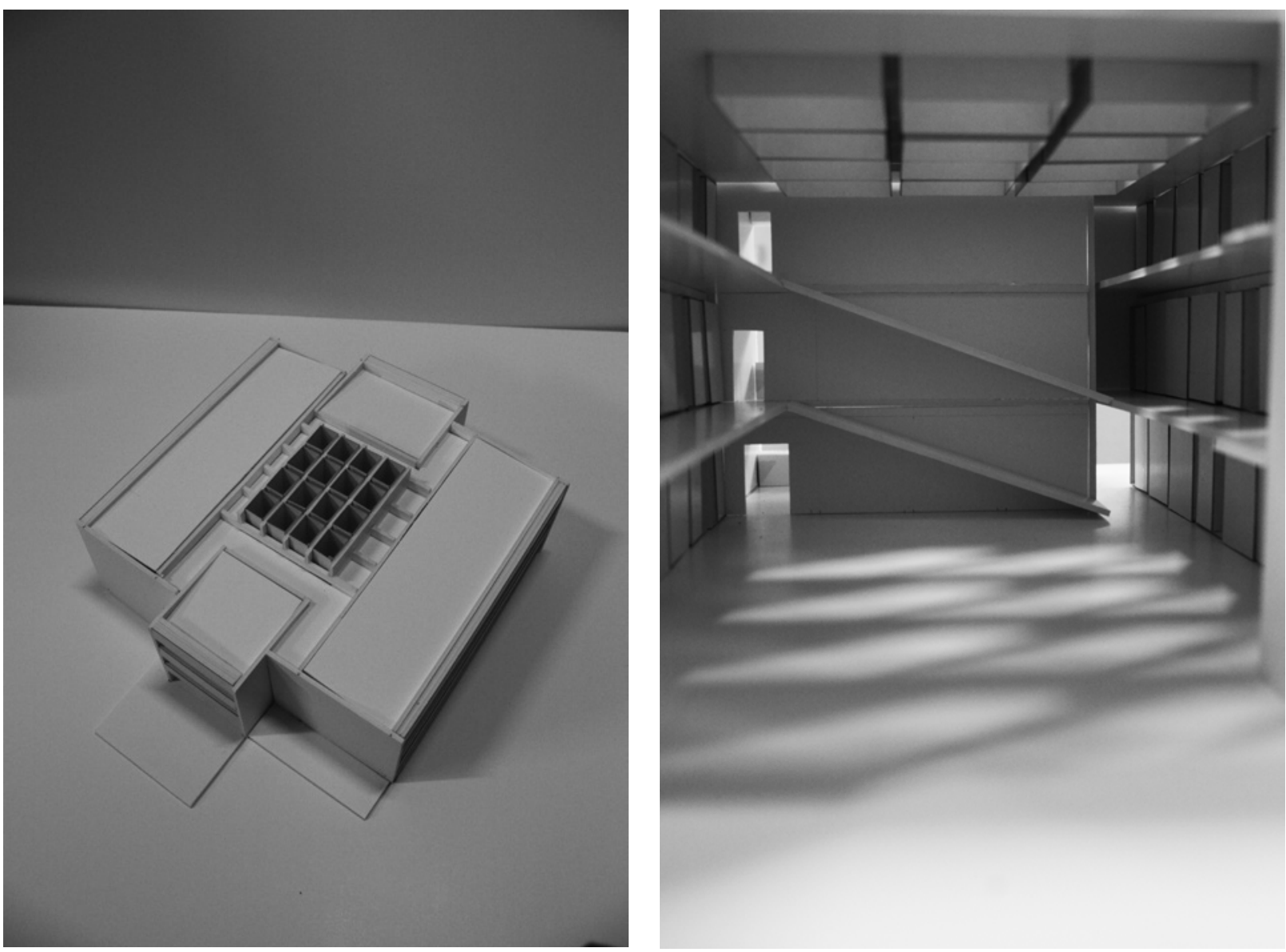


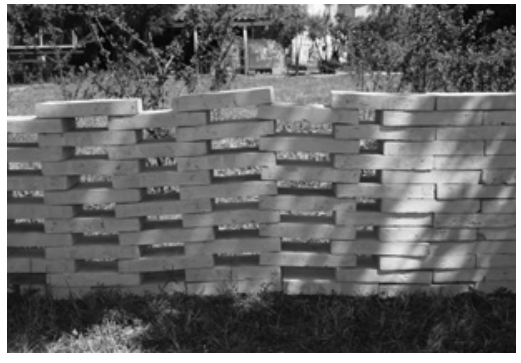

Fig. 20 Brick model @ Atelier do Corvo
The reception body represents the school community. It is through this body that students, teachers and staff will access the school. The building extends over two storeys with its main feature being the connection with the multipurpose hall. This space, a learning street placed at the hub of the large distribution corridor between the different bodies that make up the school complex, would function as a straightforward connection between the school community and the school library, but also as a space for breaks and a meeting place for students.

The building will be in white facing brick with lattices and tracery on the exterior walls that will provide illumination for different spaces with filtered light.

This body leads onto the learning street, which also extends over two storeys and allows access to the other blocks. On the ground floor, this movement always takes place inside, while on the first floor, movement is via a covered walkway. Throughout this body other parts of the curricular programme for common use can be found, which allows the limits of the spaces to be blurred and gives fluidity.

The quadrangle of the existing blocks of the 2nd cycle will be covered and will become a generous atrium leading to the rooms, but above all will allow the rooms to be more versatile and will enable new pedagogies.

In the blocks of the 3rd cycle and the secondary school, the main restructuring will be to recess the limit masonry walls of the rooms in order to mark the pre-existent structure of the buildings. This recess will house lockers.

The central triple-height atrium will be given skylights that will characterize and illuminate these two bodies, like those of the 2nd cycle, making them appropriate as break areas.

The laboratories and the design rooms will be located in another body, opposite the existing gym-sports pavilion in the school for renovation. This will undergo a thorough remodelling so as to enable it to have new uses.

There will also be two sports fields on two different levels, covered by a structure made of metallic components and covered in galvanized steel sheeting.

The service transformer and the water tank were placed together and are located in the south-west of the plot.

The 1st cycle school is located in the south-east going from the slope to the street. The entire building has one storey in which the functional programme takes place around small squares. The roofed area will also be used for ludic activities and as a playground, as well as sports. This will be the only building that will use red facing brick in order to unambiguously mark the stage of the curricular programme as having the specific characteristics for the age group for which it is intended.

$1 \rightarrow$ External Thermal Insulation Composite System

$2 \rightarrow$ Glass Fibre Reinforced Concrete 


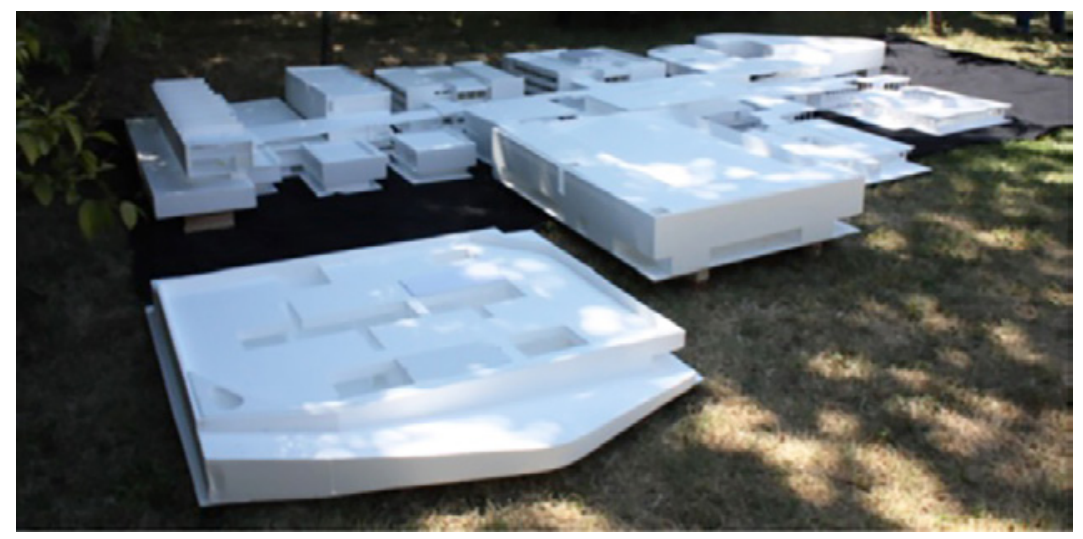

Fig. 21, 22, 23 1:50 Foam model

@ Atelier do Corvo
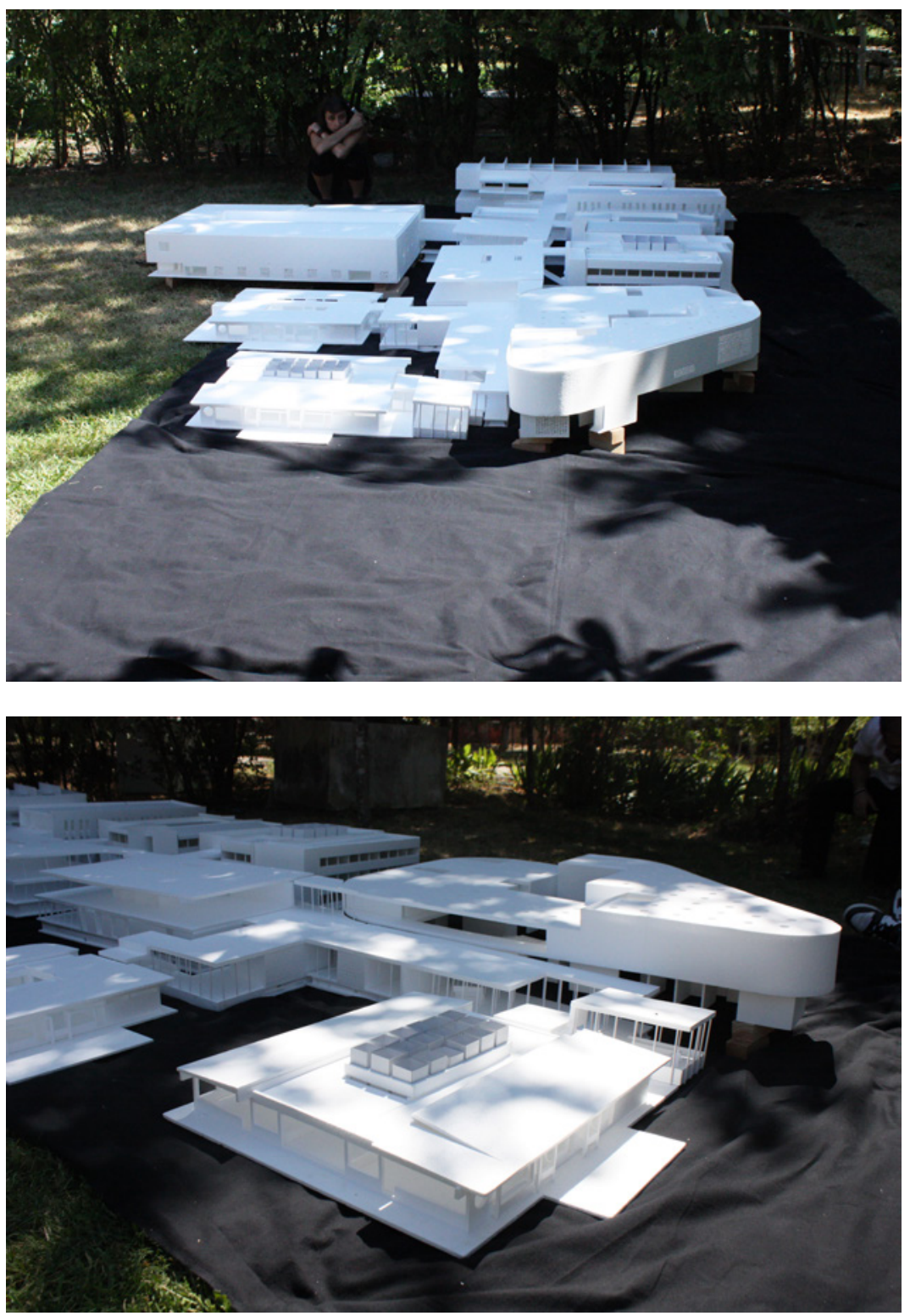